\title{
Impact of Work Motivation on Lecturer Performance Through Job Satisfaction at LL2DIKTI Indonesia
}

\author{
Tedy Ardiansyah ${ }^{1, *}$, Endry Boeriswati ${ }^{2}$, Usep Suhud ${ }^{3}$, Dewi Purwaningsih ${ }^{4}$, Nurjanah $^{5}$ \\ 1,2,3 Universitas Negeri Jakarta, Indonesia \\ ${ }^{4,5}$ Universitas Indraprasta PGRI Jakarta, Indonesia \\ "Corresponding author.Email: TedyArdiansyah_9917919003@mhs.unj.ac.id
}

\begin{abstract}
This investigation means to analyze Motivation indicator for the paintings on lecturer's execution In the Covid-19 pandemic in Indonesia, Job Satisfaction. The exploration device utilized Quantitative has been examination with an overview study philosophy directed by lecturers Indonesia-Wide, with a sum of 243 instructors. The examination gadget is an autonomous lecturer. Most Respondents were respondent's ladies as $56 \%$ with the greatest position of Assistant Expert and Assistant Expert Lector at $41 \%$ and $39 \%$, individually. A tool for exploration was assembled dependent Operationalization on the cycle of each one builds that was received and created from past examination. Information were gotten utilizing a poll. The discoveries of the examination were explained as unmistakable Inferential, and. inferential scrutiny utilizing the Structural Equation Modeling (SEM) technique utilizing Lisrel 8.8 measurable programming. The discoveries demonstrated that there has been a significant fine effect of labor inspiration at the instructor's exhibition and occupation fulfillment. On the opposite side, there is no certain. The finish of this examination add to this the impediments of the writing and discoveries that are not the same as numerous past investigations, in particular the absence of exploration utilizing the interceding variable activity fulfillment on speaker execution and assisting solution a few new examinations That didn't have added To the outcome of these factors.
\end{abstract}

Keywords: Work Motivation, Job Satisfaction, Lecturer Performance

\section{BACKGROUND}

Infection sickness known as crown (COVID-19) is a plague on this planet now. Terrifically significant angles going from wellbeing, economy, governmental issues, and instruction and furthermore securities had been shaken by the Covid-19 and have been gigantic impact Human lifestyles around the globe. Will this be it shortcoming affect the viability of lecturers at some stage in the Covid-19 pandemic? Some ongoing examinations have not had the option to address Questions to study, for example, research [1] The consequences of the investigation just spotlight on the connection between representative presentation and worker inspiration. In the interim different investigations just spotlight on the relationship between's staff inspiration and employment execution and between work fulfillment and performance [2] the equivalent is the situation with contemplates [3]. The investigation [4] reinforces HR practices and the board styles received with regards to creating position abilities, which are then just identified with work fulfillment and administration execution.

\section{LITERATURE REVIEW}

\subsection{Work Motivation}

Inspiration is a mental instrument that actuates energy, heading, quality also consistency of activities. Motivation is the yearning to try to accomplish the various leveled objections that are influenced by the limit of business to meet a part of the individual needs [5];[6];[7]. Enlivened by the association, HR are dynamically roused to endeavor to upgrade productivity and to give a valiant effort for the association [8]. Inside 
hypothesis gives inspiration the primary thought to factors inside people that advantage to inspiration plus conduct [9]. Highest inclusion plus inspiring labor pool, greatest chance of authoritative accomplishment at accomplishing objectives plus targets [10]. As indicated by [11] cases inspiration is a phrase utilized at authoritative conduct for depict quality at a person, which portrays the degree, course, and tirelessness of endeavors spent on work. In the interim, the sentiment [12] proposes at work inspiration is characterized was conditioned influences energy, course, plus conduct support applicable for work saving.

\subsection{Job Satisfaction}

Employment fulfillment is more a relic of times gone by, of an interior state. That for instance, can be connected to sentiments of individual accomplishment, either quantitatively or subjectively [10] .Employment fulfillment is portrayed as a pleasurable passionate state [13], and is a significant indicator of the conduct of hierarchical citizenship. Recollect that activity fulfillment is imperative to us since it influences numerous different variables in the work environment [9]. Work fulfillment is an essential determinant of the assessment of the activity condition [14] and for the most part positively affects representative presentation [13]. As the term work fulfillment influences a representative's enthusiastic connection to the business, whom the person in question partners with his activity, numerous natural and outward prize variables impact it. Exploration to date has recommended that, in spite of the circumstance in western nations, work fulfillment has nothing to accomplish with family-work clashes in creating nations [15] shows various understandings of the idea in creating and creating nations. Up.

\subsection{Lecturer Performance}

Representative execution was influenced with inspiration, if laborers were propelled; they could accomplish work and in the end increment their presentation[16]. This investigation examines authoritative correspondence among broadcast organization workers. As indicated by the starter meets with the executive staff from telecom organization, ongoing increment at the quantity of workers that was demand break down representative execution. [17] expressed that so as to oversee current representative execution and propel them towards better execution, effective correspondence rehearses are required in all associations. Various examinations on HR the executives rehearses have uncovered that truancy also in and out could be diminished whatever thus advance manage quality also elite with guide of nice HR rehearses. [18]. It is additionally proposed that there is a significant function in worker maintenance by HR the executives,[19].

\section{RESEARCH METHODS}

Research describes statistical research, structured to describe the per-variable relationship, in other words, variable correlation with provisional conclusion testing analysis. LLDIKTI lecturers as a sample of the population in Indonesia. Using an approach to select a sample from a determined population, namely random sampling, that in the population each respondent has the same opportunity to be sampled, it is estimated that there are 243 people. [20]determines for the lowest limit of 200 respondents, this is needed in data tabulation especially for data analysis; the approach is carried out through explanatory factorial analysis in determining the form of demonstration of Structural Equation Modeling (SEM). Another thing, in knowing indirect effects using the Sobel test, which is a test tool to determine the correlation to the intermediate variable; the aim is to find out that the mediating variable is considered useful as an intermediate variable in the relationship between variables.

The questionnaire tool to test motivation used 14 questions [21], [22], Meanwhile, measuring job satisfaction for this research uses 15 questions [21], [22], [23]. Another matter of the work environment uses 11 questions [24], [25]. Likewise, to measure lecturer performance using 20 individual performance questions[26], [27]. The total assessment of the four variables was measured using a Likert-type scale. The analysis of the display is carried out using SEM path analysis where the benefit is to answer temporary conclusions in research, the application used is the Lisrel 8.8 application.

\section{RESEARCH FINDINGS}

\subsection{Profile Sample}

Table 1 illustrates the profile calculations for 243 samples. Samples who participated in the research were lecturers working from home during the corona pandemic, all of whom came from 14 LLDIKTI 3 in Indonesia. Data is entered for a period of 5 days from 3 to 8 July 2020, all carried out during the corona pandemic in Indonesia. All lecturers work from home as well as teaching and learning activities using the internet or what is known as using e-learning. The majority of samples entered came from LLDIKTI 3 covering the 
surrounding Jakarta. The most samples are those who have positions as Expert Assistant and Lector. Another matter of the sample regarding gender is that women control at most $56 \%$, on the other hand, the majority concerns work experience of fewer than 10 years with a value of $54 \%$, on the other hand, based on the type of education $83 \%$ of the sample is lecturers who have Master's glass, the remaining $17 \%$ of the sample is strata 3 alias doctor

\subsection{Validity of the Measurement Model}

Validity analysis is used by assessing whether the questionnaire is tested or not valid, tested equal to valid, or has significant value (Riadi, 2018). Another thing from validity has the meaning of judging what is being assessed. The validity test in this research (in table 3 ) found that the final scores on the loading factors are all indicators initialized MOT1 and MOT2, the values are as follows 0.84 and 0.90 . Another thing, the values of the KIN1, KIN2, and KIN3 indicators are as follows $0.86,0.89$, and 0.83 . for other indicators $\mathrm{KEP} 1, \mathrm{KEP} 2$, and KEP3 the values are as follows $0.76,0.86$, and 0.88 .

The results produce the loading factor test, it is proven that the indicator value is higher than the critical value. It means that the resulting value in assessing the unobserved variable is greater than the loading factor for the other unobserved variables. This can be proven by indicators that have a significant value in assessing unobservable variables (Riadi, 2018). In Table 3, it describes the relationship value of each unobserved variable that is higher than AVE on other variables.

\subsection{Measurement Reliability}

The reliability test in this research (see table 3) was carried out by assessing Construct Reliability and Average Variance Extracted (Riadi, 2018). The final value describes the variables (MOTIVATION; 0.84 and 0.72), (KINERJA; 0.94 and 0.67), (SATISFACTION; 0.93 and 0.87) and (Environment; 0.86 and 0.76). intended that the reliability variable consists of several values of Construct Reliability and Average Variance Extracted which have standard provisions that apply to start at 0.70 and 0.5 (Riadi, 2018).

\subsection{Structure Model Testing}

Post conditions for the implementation of the structural model assessment, the model in this research were analyzed by the previous goodness of fit index [28]. According to the results of the model fit assessment depicted in Figure 2, the following is the value of Degrees of Freedom $=17$, Minimum Fit Function ChiSquare $=22.06(\mathrm{P}=0.18)$, Normal Theory Weighted Least Squares Chi-Square $=22.06(\mathrm{P}=0.18)$ the result is the model is formed in this research is "Good of fit". Shown or seen in Figure 2. Hybrid / Full research model. Then an assessment of the structural model is carried out where the desired goal is to assess exogenous unobserved variables with endogen unobserved variables. The final score of the assessment is proven by a hypothesis that has been formed on the basis of a significant or insignificant theoretical conceptual framework. The final value of the hypothesis assessment in the research is shown in Table 1

Table 1 . The results of testing the validity

\begin{tabular}{|c|c|c|c|c|c|}
\hline \multirow[b]{2}{*}{$\begin{array}{c}\text { Latent } \\
\text { Variable } \\
\text { (LV) }\end{array}$} & \multirow[b]{2}{*}{$\begin{array}{c}\text { LV } \\
\text { (Dimen } \\
\text { sion) }\end{array}$} & \multicolumn{3}{|c|}{ Validity } & \multirow[t]{2}{*}{ Result } \\
\hline & & $\mathrm{SFL}^{*}$ & $\mathrm{CV}$ & $\mathrm{CR}^{88}$ & \\
\hline \multirow{3}{*}{ Motivation } & & & & 0.94 & Reliable \\
\hline & MOT1 & 0.84 & 0.5 & & Valid \\
\hline & MOT2 & 0.9 & 0.5 & & Valid \\
\hline \multirow{4}{*}{ Satisfaction } & & & & 0.87 & Reliable \\
\hline & KEP1 & 0.76 & 0.5 & & Valid \\
\hline & KEP2 & 0.86 & 0.5 & & Valid \\
\hline & KEP3 & 0.88 & 0.5 & & Valid \\
\hline \multirow{4}{*}{ Performance } & & & & 0.90 & Reliable \\
\hline & KIN1 & 0.86 & 0.5 & & Valid \\
\hline & $\mathrm{KIN} 2$ & 0.89 & 0.5 & & Valid \\
\hline & $\mathrm{KIN} 3$ & 0.83 & 0.5 & & Valid \\
\hline
\end{tabular}


Table 2 . The results of the testing reliability

\begin{tabular}{|c|c|c|c|c|c|}
\hline \multirow[b]{2}{*}{$\begin{array}{c}\text { Latent } \\
\text { Variable } \\
(\mathrm{LV})\end{array}$} & \multirow[b]{2}{*}{$\begin{array}{c}\text { LV } \\
\text { (Dimen } \\
\text { sion) }\end{array}$} & \multicolumn{3}{|c|}{ Reliability } & \multirow[t]{2}{*}{ Result } \\
\hline & & $\mathrm{CV}$ & $\begin{array}{c}\text { AV } \\
E^{* 8}\end{array}$ & $\mathrm{CV}$ & \\
\hline Motivation & $\begin{array}{l}\text { MOT1 } \\
\text { MOT2 }\end{array}$ & 0.7 & 0.89 & 0.5 & $\begin{array}{c}\text { Reliable } \\
\text { Valid } \\
\text { Valid }\end{array}$ \\
\hline Satisfaction & $\begin{array}{l}\text { KEP1 } \\
\text { KEP2 } \\
\text { KEP3 }\end{array}$ & 0.7 & 0.70 & 0.5 & $\begin{array}{c}\text { Reliable } \\
\text { Valid } \\
\text { Valid } \\
\text { Valid } \\
\text { Valid }\end{array}$ \\
\hline Performance & $\begin{array}{l}\text { KIN1 } \\
\text { KIN2 } \\
\text { KIN3 }\end{array}$ & 0.7 & 0.74 & 0.5 & $\begin{array}{c}\text { Reliable } \\
\text { Valid } \\
\text { Valid } \\
\text { Valid }\end{array}$ \\
\hline
\end{tabular}

$\mathrm{VE}^{8 * 8}=$ Variance Extracted. Source: Research Data (2020)

\subsection{Testing of the hypothesis}

This research is divided into four hypotheses (in Table 4). The hypothesis is assessed on the standard t-test calculation, namely Ho is rejected when the t-value is higher than the critical $\mathrm{t}$ value or the $\mathrm{Z}$ score is 1.64 (one-tail test) for $\alpha=0.05$.

Research one assesses the associative parts of hypotheses one, two, and three. Research 2 assesses indirect correlation as part of hypothesis four. The partially indirect significant assessment (intermediary hypothesis assessment) is carried out as follows:

The system steps the Sobel test (Kline, 2011: 164). The Sobel test is run through a correlation strength test of the unaffected indirect variable $(X)$ to the affected variable (Z) across the variable $(\mathrm{Y})$. Indirect correlation $\mathrm{X}$ to $\mathrm{Z}$ across $\mathrm{Y}$. Rated in terms of multiplication path $\mathrm{X} \rightarrow \mathrm{Y}$ (a) by path $\mathrm{Y} \rightarrow \mathrm{Z}$ (b) or ab. So the coefficient $\mathrm{ab}=$ (c $\left.\mathrm{c}^{\prime}\right)$, including $\mathrm{c}$ is the effect of $\mathrm{X}$ on $\mathrm{Z}$ without keeping an eye on $\mathrm{Y}$, thus $\mathrm{c}^{\prime}$ is the correlation coefficient of $\mathrm{X}$ against $\mathrm{Z}$ after. Supervise $Y$. Standard error coefficients $\mathrm{a}$ and $\mathrm{b}$ wrote in $\mathrm{Sa}$ and $\mathrm{Sb}$, the magnitude of the indirect effect.

The final value of the calculation of the structural model using SEM-Lisrel is described in Table 4. Hypothesis 1 shows that the coefficient value of the variable pathway of work motivation on lecturer performance is 9.22 higher than the $\mathrm{t}$-critical value of 1.64 . It is meant that the level of confidence is $95 \%$ and $\alpha=5 \%$, Ho is rejected and $\mathrm{H} 1$ is accepted, which means that the coefficient of a direct effect of work motivation on performance is significant with a coefficient of determination of $\mathrm{R} 2$ of 0.94 . The results obtained, hypothesis 1 which forms a positive and significant influence of motivation on Lecturer Performance, is significant. Hypothesis 2 describes the value of the coefficient score of the variable pathway of work motivation on job satisfaction of 9.99 , greater than the $t-$ critical value of 1.64 . This means that at the confidence level of $95 \%$ and $\alpha=5 \%$, Ho is rejected and $\mathrm{H} 2$ is accepted, for that it is translated into a coefficient of a direct effect of work motivation on job satisfaction is significant with a coefficient of determination of R2 of 0.75 . So for that, hypothesis 2 is described as having a positive and significant effect. Work motivation for lecturer performance is acceptable. Hypothesis 3 illustrates that the path coefficient score of the variable job satisfaction on lecturer performance is -1.1 smaller than the $\mathrm{t}$-critical value of 1.64 . It means that the confidence level is $95 \%$ and $\alpha=5 \%$, Ho is accepted and $\mathrm{H} 4$ is rejected, and it is stated that the coefficient of a direct effect of job satisfaction on lecturer performance is not significant with a coefficient of determination of $\mathrm{R} 2$ of -0.1 . Therefore, hypothesis 3 describes that there is no positive and insignificant influence on job satisfaction on lecturer performance is unacceptable. Hypothesis 4, illustrates that for the $\mathrm{Z}$ value the path coefficient score is calculated through the "Sobel test" formula, for that the effect of work motivation variables on lecturer performance through job satisfaction is 0.52 smaller than the t-critical value of 1.64 . This means that at the confidence level of $95 \%$ and $\alpha=5 \%$, Ho is accepted and $\mathrm{H} 4$ is rejected, therefore it is concluded that the coefficient of an indirect effect of work motivation on lecturer performance through job satisfaction is not significant with the coefficient of determination of $\mathrm{R} 2$ of 0.145 . Thus, hypothesis 4 which states that there is a positive and significant indirect effect of work motivation on lecturer performance through job satisfaction cannot be accepted. 


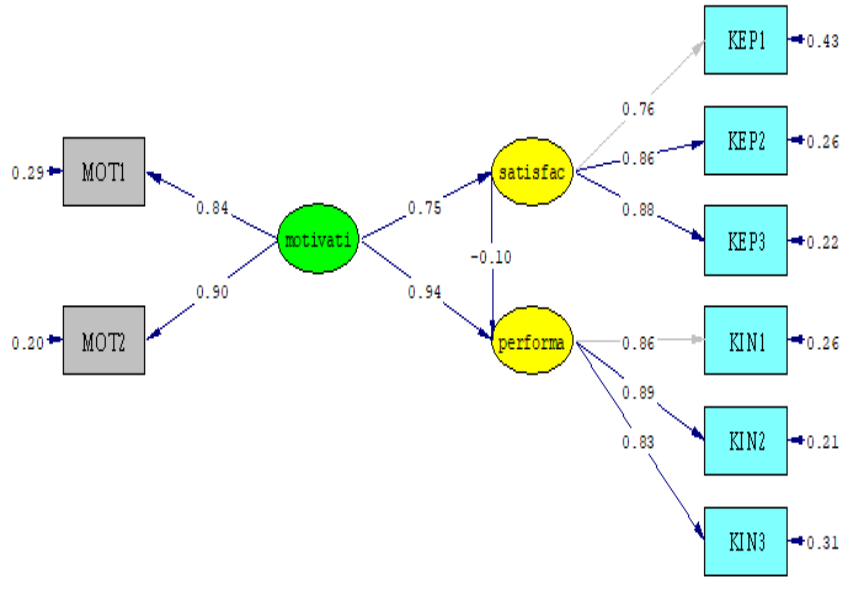

Chi-Square $=22.06, d f=17, p-$ value $=0.18258$, RMSEA $=0.035$

\section{DISCUSSION}

\subsection{Correlation work motivation for lecturer performance}

Proven directly, the value of this research illustrates the significance of the motivation for lecturer performance. This research has been proven to be reviewed from several previous studies ([29]; [30]; [31]; [32]; [4]; [22] According to [6], the results of the research illustrate the proven correlation of employee performance to work motivation. Indexed indicators are emulated from research [5], as well as empirical evidence of the value of answers from the sample Addressing lecturers significantly has positive work motivation in a correlation that shows positive performance while working. Meanwhile, the final value of the research illustrates that lecturers are good at being motivated in their field of work, as illustrated in the phase of lecturer pride continuing to work in current situations that are less profitable, especially the lack of process learning during the Corona pandemic in Indonesia All lecturers are sure to work seriously in the learning process with great care students, both for research and community service. Lecturers feel a work-life balance by working at home, especially close to their family, compared to the previous period; the benefits they get are more freedom to do work with the freedom to manage their own time and more time for their wives and children.

\subsection{Correlation Work motivation to satisfaction at work}

As direct evidence, the value of research illustrates the correlation between motivation and job satisfaction. This research represents previous research [33]. Also provides resistance from previous research [34]; [21]besides that, it shows no proven relationship between work motivation and job satisfaction. The final test score of the correlation of 2 variables, including work motivation and job satisfaction, has been discussed previously. In accordance with a series of indicators that are emulated from research [21] and [22], according to the description of the sample results, where lecturers have attached high work motivation, will automatically lead to satisfaction at work. will always be motivated at work, this picture is manifested by the support from managers or superiors directly for learning to use the internet at the time of the corona pandemic at this time, automatically illustrating the satisfaction in the work of lecturers Besides that, satisfaction at work gets support, especially regarding the free time policy which is managed wisely by the lecturers.

\subsection{Job satisfaction on Lecturer Performance}

Observationally, aftereffects the examination describe for this no evident impact at workplace between effort inspiration. This exploration negates contemplates ([23]; [14]; [28]; [26]. Notably, from all respondents who replied, instructors by and large differ between work fulfillment and lecturers execution. This can be demonstrated that each lecturers can't augment work when the consequences of examination or network administration are completed on the web, there are things that is impossible, for example, disconnected, for instance When doing explore on the web, it is somewhat hard for accentuate respondents to gather surveys or while doing network administration networked is agerestricted (Using an unpaid application) so the predefined target isn't accomplished.

\subsection{Motivation for Lecturer Performance through Job Satisfaction}

Observationally, aftereffects that examination can't demonstrate that there is an impact of work inspiration on instructor execution through employment fulfillment. In light of the appropriate responses of direct samples inquiries, it's very well may be clarified at the time corona pandemic, Motivation to specific approach can advance Lecturer execution, example to instance effort in house a ton of age for the children and wife, that could in a roundabout way improve Lecturer execution. The greatest impact perceive through the lecturers is big 
inspiration forward online education (on the web) instruction and their work, having the option to keep on functioning admirably, even In the Covid-19 Pandemic. Yet, actually, when joined with the intercession variable of fulfillment, the lecturers isn't maximal in performing, implying that inspiration alone isn't finished with greatest work which will bring about horrible showing of the speaker, for instance instructors have high inspiration but since they are acclimated with working disconnected, when web based learning is a ton encountering snags, for example, not yet acing eLearning learning innovation, eLearning learning measure, restricted web standard, network that is consistently steady just at specific hours and others so it makes not exactly ideal execution for instructors.

\section{CONCLUSION}

A few past investigations have clarified that work inspiration has positively affected lecturer's execution and employment fulfillment. Be that as it may, from this examination, work fulfillment negatively affects lecturers' execution. Through this examination, clarification and affirmation of the exploration, mostly fortifies and somewhat invalidates existing ideas. In a few different ways the aftereffects of the investigation concur with past exploration, specifically that work inspiration positively affects lecturers' execution and occupation fulfillment. In any case, as far as the effect of employment fulfillment on speaker execution, this investigation gives discoveries that are not the same as numerous past examinations. The similitudes and contrasts in the discoveries of this investigation with past examination can be clarified that this exploration was completed on instructors all through Indonesia where the greater part in this poll were aide specialists and lecturers.

By and large, work fulfillment during the Covid pandemic has diminished regarding instructor execution. Ineffectively ill-equipped guidelines administering work measure systems, culture stun that changes disconnected work examples to on the web, workplaces, authority designs and lacking dominance of innovation in webbased learning

\section{RESEARCH SUGGESTION}

This examination was performed in light of the current situation of the Covid-19 pandemic, which had a significant mental impact on respondents, particularly speakers. A few perspectives, for example, fund, innovation, sexual orientation, social transformation, authority of information and aptitudes in the eLearning learning cycle and administration in this examination are as yet dismissed with the goal that they should be incorporated as indicator factors in resulting research. Regarding the system of spellbinding investigation, it has not had the option to distinguish all the more profoundly all the practices related with the build of this examination, so further exploration is proposed to affirm the aftereffects of the poll through the meeting cycle.

\section{ACKNOWLEDGMENTS}

This investigation might want for acknowledge ICONETOS 2020 board to chance for introduce that logical transcript; ideally would be valuable at assisting with finishing the Management knowledge Doctor theory.

\section{REFERENCES}

[1] R. Niswaty, R., Rusbiati, S., Jamaluddin, J., \& Salam, "The Influence of Teacher's Reinforcement for Students Motivation.," Int. Conf. Educ. Sci. Art Technol., pp. 148-152, 2017.

[2] O. A. Acar, "Motivations and solution appropriateness in crowdsourcing challenges for innovation.," Res. Policy., 2018.

[3] A. Hewagama, G., Boxall, P., Cheung, G., \& Hutchison, "Service recovery through empowerment? HRM, employee performance and job satisfaction in hotels.," Int. J. Hosp. Manag., vol. 81, pp. 73-82., 2019.

[4] D. Nurhuda, A., Purnamasari, W., Irawan, N., Nurhidayati, F., Mahmudah, S., Anshori, M., Yahya, "Effect of Transformational Leadership Style, Work-Discipline, Work Environment on Employee Motivation and Performance.," J. Phys. Conf. Ser., vol. 1175, no. 1, 2019.

[5] O. A. Tella, A., \& Ibinaiye, "Correlates of staff motivation, satisfaction, and job performance of library staff in selected Nigerian University libraries.," Int. Inf. Libr. Rev., vol. 52, no. 1, pp. 32-49, 2020.

[6] C. Girdwichai, L., \& Sriviboon, "EMPLOYEE MOTIVATION AND PERFORMANCE: DO THE WORK ENVIRONMENT AND THE TRAINING MATTER?," J. Secur. Sustain. ISSUES, vol. 9, no. 4, pp. 42-55., 2020.

[7] H. Saggaf, M. S., Nasriyah, N., Salam, R., \& Wirawan, "The Influence of Teacher's Pedagogic Competence on Learning Motivation of Student of Office Administration Expertise Package.," in In Conference: 8th International Conference of Asian Association of Indigenous and Cultural Psychology (ICAAIP 2017)., 2018. 
[8] H. N. Ningsi, C. A., Alhabsji, T., \& Utami, "Pengaruh Pelatihan Dan Promosi Terhadap Motivasi Dan Kinerja Karyawan (Studi Pada Karyawan Pt. pln (Persero) Area Kendari).," J. Ilm. Ilmu Adm. Publik, vol. 5, no. 2, pp. 131-143., 2016.

[9] J. C. Nelson, D. L., \& Quick, Organizational Bahaviour. Cengage Learning, 2018.

[10] L. J. Mullins, "Management \& Organisational Behaviour (eleven (11))," United Kingdom: Pearson Education Limited., 2016. .

[11] A. M. Grant, "Leading with meaning: Beneficiary contact, prosocial impact, and the performance effects of transformational leadership.," Acad. Manag. Journal, vol. 55, no. 2, pp. 458-476., 2012.

[12] R. D. Webb, J. W., Bruton, G. D., Tihanyi, L., \& Ireland, "Research on entrepreneurship in the informal economy: Framing a research agenda.," J. Bus. Ventur., vol. 28, no. 5, pp. 598-614., 2013.

[13] B. Al Jenaibi, "Job Satisfaction: Comparisons among diverse Public Organizations in the UAE.," Manag. Sci. Eng., vol. Vol. 4, no. 3, pp. 60-79, 2010.

[14] R. P. J. Sharma, P., Kong, T. T. C., \& Kingshott, "Internal service quality as a driver of employee satisfaction, commitment and performance: Exploring the focal role of employee well-being.," J. Serv. Manag., vol. 27, no. 5, pp. 773-797., 2016.

[15] R. and Y. S. Namayandeh, H., Juhari, "The effects of job satisfaction and family satisfaction on workfamily conflict and family-work conflict among married female nurses in Shiraz-Iran.," Asian Soc. Sci., vol. 7, no. 2, pp. 88-95., 2011.

[16] A. A. Azar, M., \& Shafighi, "The effect of work motivation on employees' job.," Int. J. Acad. Res. Bus. Soc. Sci., vol. 3, no. 9, pp. 1-9., 2013.

[17] K. Rajhans, "Effective organizational communication: A key to employee motivation and performance.," Intersci. Manag. Rev., vol. 2, no. 2, pp. 81-85., 2012.

[18] D. E. Guest, "Human resource management and employee well-being: Towards a new analytic framework.," Resour. Manag. J., vol. 27, no. 1, pp. 22-38., 2017.

[19] F. Boer, H., Berger, A., Chapman, R., \& Gertsen, "CI Changes from Suggestion Box to Organisational Learning: Continuous Improvement in Europe and Australia.," Contin. Improv. Eur.
Aust. Routledge., 2017.

[20] V. Hair Jr, J., Sarstedt, M., Hopkins, L., \& G. Kuppelwieser, "Partial Least Squares Structural Equation Modeling (PLS-SEM) An Emerging Tool in Business Research.," Eur. Bus. Rev., vol. 26, no. 2, pp. 106-121., 2014.

[21] S. Š. Grujičić, M., Bata, J. J., Radjen, S., Novaković, B., \& Grujičić, "Work motivation and job satisfaction of health workers in urban and rural areas.," Vojnosanit. Pregl., vol. 73, no. 8, pp. 735-743., 2016.

[22] O. A. Tella, A., \& Ibinaiye, "Correlates of staff motivation, satisfaction, and job performance of library staff in selected Nigerian University libraries.," Int. Inf. Libr. Rev., vol. 52, no. 1, pp. 32-49., 2020.

[23] P. Siengthai, Sununta, \& Pila-Ngarm, "The interaction effect of job redesign and job satisfaction on employee performance.," EvidenceBased HRM, vol. 4, no. 2, pp. 162-180., 2016.

[24] S. Pawirosumarto, "The effect of work environment, leadership style, and organizational culture towards job satisfaction and its implication towards employee performance in Parador hotels and resorts, Indonesia.," Int. J. Law Manag., vol. 59, no. 6, pp. 1337-1358., 2017.

[25] J. Samson, G. N., Waiganjo, M., \& Koima, "Effect of Workplace Environment on the Performance of Commercial Banks Employees in Nakuru Town.," Int. J. Manag. Stud. Res., 2015.

[26] M. I. Hendri, "The mediation effect of job satisfaction and organizational commitment on the organizational learning effect of the employee performance.," Int. J. Product. Perform. Manag., 2019.

[27] M. Kissi, E., Asare, O. A., Agyekum, K., Yamoah Agyemang, D., \& Labaran, Mamoah Agyemang, D., \& Labaran, "Ascertaining the interaction effects among organisational citizenship behaviour, work overload and employees' performance in the Ghanaian construction industry.," Int. J. Product. Perform. Manag., vol. 68, no. 7, pp. 1235-1249., 2019.

[28] S. Riyadi, "the Influence of Job Satisfaction, Work Environment, Individual Characteristics and Compensation Toward Job Stress and Employee Performance.," Int. Rev. Manag. Mark., vol. 9, no. 3, pp. 93-99., 2019.

[29] A. So, I. G., Noerlina, Djunggara, A. A., Fahrobi, R., Simamora, B. H., \& Ruangkanjanases, "Effect of organisational communication and culture on 
employee motivation and its impact on employee performance.," Pertanika J. Soc. Sci. Humanit., vol. 26, no. 2, pp. 1133-1142., 2018.

[30] M. Rita, "Moderating effect of organizational citizenship behavior on the effect of organizational commitment, transformational leadership and work motivation on employee performance.," Int. J. Law Manag., vol. 60, no. 4, pp. 953-964., 2018.

[31] J. C. Beltrán-Martín, I., \& Bou-Llusar, "Examining the intermediate role of employee abilities, motivation and opportunities to participate in the relationship between HR bundles and employee performance.," BRQ Bus. Res. Quarterly, vol. 21, no. 2, pp. 99-110., 2018.
[32] M. W. Mulyani, S. R., Sari, V. N., \& Sari, "The model of employee motivation and cooperative employee performance.," Polish J. Manag. Stud., vol. 20, no. 2, pp. 379-390., 2019.

[33] H. Suttikun, C., Chang, H. J., \& Bicksler, "A qualitative exploration of day spa therapists' work motivations and job satisfaction.," J. Hosp. Tour. Manag., vol. 34, pp. 1-10., 2018.

[34] V. Anghelache, "A Possible Explanatory Model for the Relationship between Teaching Motivation and Job Satisfaction.," Procedia - Soc. Behav. Sci., vol. 180, pp. 235-240, 2015. 